\title{
Structuring and Recreating Inequality: Health Testing Policies, Race, and the Criminal Justice System
}

Research shows that prison inmates have a higher risk of contracting HIV/AIDS than the general population, prompting widespread measures aimed at diagnosing, quarantining, and treating inmates. Yet, recent scholarship has linked the release inmates to an increase in the HIV incidence rate of various communities. In this paper we explore the disjuncture between institutional policies and potential community outcomes by evaluating health assessments of inmates before, after, and during admission to prison. We argue that the penal institution is an active agent in structuring and recreating health inequalities within prisons, thereby exacerbating existing community health inequities when inmates are released from prison. Using data from the 2002 Survey of Inmates in Local Jails and the 2004 Survey of Inmates in State and Federal Prisons, we find significant racial, educational, and marital inequalities in health testing and test results. We show that these inequalities vary across types of institutional testing policies and inmate cohorts, with later admission cohorts being less likely to receive HIV tests and future release cohorts having a higher likelihood of being HIV-positive.

Bryan L. Sykes

University of Washington

Alex R. Piquero

University of Maryland 


\section{INTRODUCTION}

Issues of race and crime are 'mired in an unproductive mix of controversy and silence' (Sampson and Wilson, 1995), which remain among the most critical issues facing social scientists. Two issues that have received sustained research attention are crime/imprisonment and health disparities. Yet, while researchers have paid significant attention to each of these, they have not sufficiently explored their interconnections, which are to be strongly suspected given the significant differences observed in both the prevalence and frequency of imprisonment that non-whites are subject to as well as the significant differences observed in communicable diseases differentially born by minorities, especially those who are imprisoned.

Health disparities and risk of incarceration are strongly race and class based. Research shows that incarceration is a new stage in the life-course of undereducated men, with $60 \%$ of black men with less than a high school education expected to serve time prison (Pettit and Western 2004). The communities from which these men are drawn suffer from high rates of morbidity and mortality as a consequence of various family and health disparities (Lynch and Sabol 2004; Sabol and Lynch, 2003; Piquero et al. 2006; Rich 2000; Williams and Collins 1995). One such health disparity is the prevalence and incidence of HIV. While a growing body of work has focused on the spread of communicable diseases in prisons (Hammett et al., 2002), recent scholarship has linked the incidence of HIV in communities to the release of inmates (Raphael and Johnson 2007). The connection between inmate release and new cases of HIV is important because racial inequality in criminal justice may bear some linkage in exacerbating community health disparities. In this paper we examine one consequence of racialized 
patterns in crime and justice that may be related to research on inmate release and community health outcomes: racial disparities in HIV testing and prevalence before and during admission to prison.

This topic is important for several reasons. First, scholars have documented a variety of negative consequences related to serving time in prison. Labor market and marital prospects, reoffending, mental health, political involvement, and physical health have all been found to be negatively associated with having spent time in prison. Yet researchers have overlooked one potentially positive externality related to entering prison: inmates’ gaining access to institutionalized healthcare. Despite the persisting racial and ethnic disparities in health care use (Fiscella et al. 2002), research shows that there are no significant racial differences in the rates of screening services or immunizations (Williams et al. 2001), with black patients accessing primary care for preventative services at equal or greater rates than white patients. These findings indicate that one pathway by which health disparities may be mollified is through an institutional approach that enables incoming and outgoing cohorts to be tested, diagnosed, and possibly treated for various diseases.

Moreover, this topic important because inmates are at a higher-risk of contracting HIV/AIDS than the general population (Maruschak 2006), which has implications for the health of the communities when flows of inmates are released. Empirical work on the topic has largely focused on measuring and accounting for the pervasiveness of the disease among inmates (Braithwaite and Arriola 2003; Maruschak 2004); determining if and how the disease is transmitted within these institutions (Horsburgh et al. 1990); and evaluating effective programs for treatment and prevention (Nicholson-Crotty and 
Nicholson-Crotty 2004). However, few studies have focused on how health testing at admission to prison structures and recreates health inequalities among prisoners and communities. The penal system is an ideal case study for examining the role institutions play in shaping and structuring particular health outcomes because inmates receive medical evaluations when admitted to prison. State and prison policies aimed at evaluating the health of inmates are highly structured, with observed health disparities occurring as a result of the practices and processes whereby some inmates receive health evaluations while others do not. Systematic differences by race and socio-economic status, due to discrimination and racism, would mean that prisons structure health inequalities internally and that they recreate the very health inequities inmates would likely endure outside the penal system.

\section{STRUCTING INEQUALTY}

Little is known about prison and jail policies regarding HIV testing and treatment. In fact, the circumstances wherein inmates are tested for HIV is highly variable; inmates in jails and prisons are subject to different testing guidelines depending on when and where they enter and exit jail/prison. For instance, in 2004, eighteen states had policies specifically aimed at testing all inmates matriculating into state prisons and local jails, while only two states had policies for testing inmates in custody and three states tested prisoners upon release (Maruschak 2004) . In 2000, however, nineteen states tested all inmates for HIV, five states tested all inmates in custody, and the federal government, in addition to three states, tested all inmates upon release (Maruschak 2000). This shift in federal policy—from testing all inmates upon release to only testing high risk groups— represents an institutional change that could have significant import for understanding 
how institutions structure health inequalities for inmates and the communities that absorb them upon release. The move away from testing inmates upon release to testing high risk groups means that the federal system determines who is "most" at risk, and such a policy does not guarantee that an inmate's HIV status did not change while incarcerated. In fact, in 2004, only one state (Alabama) tested all inmates entering and leaving state custody, whereas in 2000, three states (Alabama, Missouri, and Nevada) did so. These changes in federal and state policies could have direct and measureable effects for matriculating and exiting cohorts, and these policy changes mean that the very knowledge an inmate has about his HIV status is determined by institutional guidelines.

\section{RECREATING INEQUALITY}

While it is possible that state and federal policies can structure and create health disparities for inmates, such an institutional intervention means that prisons and jails can also ameliorate health inequalities depending on the policy, the state, and when the inmate is exposed to the policy. Yet, given the variability in testing policies across states and time, it is also possible that jails and state/federal prisons recreate the very health disparities that plague an inmate's sending community. We test whether prisons/jails recreate health inequalities by comparing model estimates of inmates who did not receive an HIV test at admission but were ever tested (i.e., tested prior to incarceration) to similar inmates who were tested at admission to prison. If prisons/jails do not recreate health inequalities by race and socio-economic status, model estimates should be similar on that demographic indicator. However, if inmates who were tested at admission have lower chances of being tested, relative to inmates who were tested outside the prison system, this would mean that prisons and jails are recreating health inequalities because many 
low income, non-white neighborhoods suffer from low rates of STD testing. Such a finding would indicate that racial and socio-economic differences in health assessments—-before and during admission to prison—could have devastating consequences for the inmate's home community when they return because confinement increases their likelihood of encountering an HIV-positive inmate. Forecasting the health and health needs of inmates released from prison by cohort would enable communities to prepare for waves of inmates with varying health needs, and in this regard would inform and serve an important policy-relevant issue. This paper accomplishes this goal by examining HIV testing before and during admission to prison, and in so doing, emphasizes the understudied interconnections between race, imprisonment, and health.

\section{DATA}

We pool data are from the 2004 Survey of Inmates in State and Federal Correctional Facilities (SISFCF) and the 2002 Survey of Inmates in Local Jails (SILJ). Men and women in the SISFCF were separated into two sex-specific sampling frames. Respondents were randomly chosen from a two-stage sampling design, where the first stage relies on data from the 2000 Census of State and Federal Correctional Facilities, and the second stage sampled respondents from a list of inmates who used a bed the previous night. ${ }^{1}$ After numbering the list, a comuterized algorithm randomly selected 18,185 inmates in federal and state prisons.

Similarly, the SILJ has a two-stage sampling frame where jails and inmates were selected in the first and second stages, respectively. In the first sampling stage, approximately 460 jails were selected from six separate strata based on the population

\footnotetext{
${ }^{1}$ A complete description of the two-stage sampling frame for both sexes can be found in the 2004 SISFCF codebook.
} 
counts of men, women, and juveniles in each jail, resulting in 6,982 male and female respondents sampled from local jails. In all, there are 25,167 male and female inmates in our sample of local, state, and federal institutions.

\section{MEASURES}

There are two types of dependent dichotomous variables in our analysis: whether the inmate received an HIV test and whether the inmate tested positive for HIV. There are two measures of HIV testing: one asks whether the inmate was tested during the prison admission process and if he knew the test results. If the inmate was not tested at admission to prison, the inmate was asked if he ever had an HIV test prior to being admitted to prison, with a follow up question inquiring about his HIV status. Very few inmates admitted to prison without an HIV test were aware of the test result, hindering estimation of how their HIV status is influenced by their demographic and cohort characteristics. For either measure of HIV (i.e., tested at admission vs. tested prior to admission), there are no questions about treatment for HIV-positive inmates during incarceration. Our analysis accounts for several important independent predictors associated with health disparities, including age, race/ethnicity, education, and marital status. A complete description of all variables is listed in Table 1.

\section{METHODS \& MODELS}

We estimate the probability of being tested and testing positive for HIV using a logistic regression model (1) that includes a vector of $\left(\mathbf{X}_{\mathbf{i}}\right)$ individual level demographic characteristics and two sets of cohort fixed effects. We also include state fixed effects $\left(\delta_{\mathrm{s}}\right)$ 
in order to capture the unobserved heterogeneity occurring within states over time (e.g., different crime rates and different criminal justice system/corrections responses). ${ }^{2}$

$$
\log \left(\operatorname{Pr}\left(\mathrm{y}_{\mathrm{i}=1}\right) / \operatorname{Pr}\left(\mathrm{y}_{\mathrm{i}=0}\right)\right)=\alpha+\beta \mathbf{X}_{\mathbf{i}}+\gamma_{\mathrm{t}}+\lambda_{\mathrm{t}+\mathrm{k}}+\theta_{\mathrm{p}}+\delta_{\mathrm{s}}+\varepsilon_{\mathrm{i}}
$$

The first cohort effect $\left(\gamma_{t}\right)$ represents the period of matriculation into prison. We include this cohort effect for several reasons. First, with the rise of crimes (and especially drug markets and ensuing use) and mass incarceration during the mid 1980s and into the 1990s, it is possible that different matriculating cohorts experienced different health needs. Given racial disparities in crime and incarcerations rates, the propagation of mass incarceration through the 1990s could result in later cohorts having greater health disparities because of the disproportionate rise in the number of men incarcerated by race across cohorts. This assumes that the underlying propensity for the disease does not decline. Yet, the promulgation of safe sex and health initiatives surrounding HIV prevention gained momentum in the early to mid 1990s, which may have affected the health composition of cohorts entering prison. Our cohort effects for prison admission capture how the health of each entering cohort changes in the presence of mass incarceration and public health initiatives.

Additionally, we include a second set of cohort effects $\left(\lambda_{t+k}\right)$ that forecasts how inmate release may affect community health. ${ }^{3}$ If different release cohorts are less likely to have been tested for HIV, or if different release cohorts have a higher probability of being HIV-positive, then these cohort-specific terms could help explain why HIV incidence rates wax and wane across communities and states over time when correlated with flows from prison.

\footnotetext{
${ }^{2}$ Standard errors are clustered at the state-level to account for variance in inmate responses across states.

${ }^{3} \mathrm{~T}$ represents when the individual entered prison and $\mathrm{k}$ is a scalar for the length of his sentence. $\mathrm{T}+\mathrm{K}$ is the year in which he is to be released from prison.
} 
Furthermore, we include policy indicators $\left(\theta_{\mathrm{p}}\right)$ to capture differences in HIV testing guidelines for inmates in state, federal, and local custody. If the policies matter for structuring health inequalities, we expect to find significant testing and health differences between inmates in institutions where the policies exist.

\section{HIV TESTING}

We examine whether there are systematic differences in HIV testing in prison at the time of admission net of other factors. Table 2 displays results from our multivariate logistic regression model of being tested for HIV. Models 1-3 estimate the likelihood of being tested for HIV at admission and Models 4-6 the probability of ever being tested for HIV if the inmate was not tested at admission. Our models include controls for a set of socio-economic characteristics, institutional types, and testing policies.

Men are $14 \%$ less likely to have been tested at admission than women. Yet, this disparity increases for inmates who were not tested at admission. Men are about $41 \%$ less likely to have ever been tested for HIV outside penal intervention. The sizeable widening of the gender gap indicates that institutional intervention has narrowed HIV testing disparities between men and women.

We find significant differences in HIV testing prior to and during admission to prison. Blacks have significantly greater odds of being tested for HIV at admission than Whites (by about 29\%), and if inmates were not tested at admission, black inmates are 33\% more likely to report ever having an HIV test, relative to similar whites. Yet, significant racial disparities exist for Latinos and Asian inmates. In models 1-3, there was one significant difference between whites and Latinos/Asians in being tested at admission, but when considered alongside self-initiated testing, racial differences emerge 
quite strongly. Latinos and Asians are about 33\% less likely to ever have been tested for HIV, relative to whites. Although the odds of being tested at admission were lower for Latinos/Asians (model 2), as compared to whites, the testing gap widened significantly in the absence of institutional intervention. This suggests that institutionalization may have narrowed HIV testing differences between whites and Latinos/Asians but not blacks. Penal policies and institutionalization have recreated the likelihood that blacks being tested for HIV are approximately the same prior to and during admission to prison.

Inmates with a high school education are $16 \%$ less likely to have been tested than inmates with some college education or more. Educational disparities in testing at admission do not appear to be salient after accounting for institutional factors (model 3), but the same is not true for inmates who were tested prior to incarceration. High school dropouts are about $27 \%$ less likely to have ever been tested for HIV, relative to inmates with some college education, and these significant differences hold after accounting for the type of institution and testing policy. Institutionalization appears to attenuate the testing disparities between inmates with the most and least amount of education.

Marital status is a significant predictor of being tested, with separated and divorced/widowed inmates being 21-24\% more likely to be tested than married of similar characteristics. Controlling for penal institution and testing policies do not attenuate these findings, but these marital differences do not exist among inmates who have been tested outside the penal system, indicating that the penal system may differentially determine which martial status matters for HIV testing.

When an inmate matriculates into prison has a significant impact on whether s/he will be tested for HIV. Inmates admitted between 2000 and 2003 are 25-38\% less likely 
to have been tested for HIV at admission than inmates who were in custody prior to 1990 . Yet, among inmates tested outside the penal system, the 2000-2003 admission cohort has significantly greater odds of being tested than earlier cohorts. It is possible that the shift away from institutional testing since 2000 may have occurred in tandem with individualized responsibility for testing prior to incarceration.

Additionally, we examine whether there are significant testing differences among expected release cohorts. Inmates expected to be released between 2005 and 2009 have a significantly greater odds of being released than inmates in the 2003-2004 cohort, but this finding disappears when institution and policies are controlled. Yet, among inmates tested prior to incarceration, the 2005-2009 cohort is about $18 \%$ less likely to have been tested for HIV. Inmates to be released between 2010 and 2014 are about 20\% less likely to have been tested at admission, and cohort inmates tested outside the penal system are about 39\% less likely to have been tested. Inmates who have had their HIV status assessed prior to incarceration and expected to be released after 2020 are about 31\% less likely to have been tested, even though there are no systematic HIV testing differences at the time of admission. These findings suggest that the release of certain cohorts may have some effect on future community health outcomes given structural and personal differences in testing.

We also find that where an inmate is serving time significantly predicts whether or not s/he is tested at admission. Inmates in local jails are 65 to $72 \%$ less likely to be tested at admission than federal inmates. Among inmates tested prior to incarceration, imprisonment in local jail is associated with 35-39\% reduction in the odds of ever being tested for HIV. Prisoners in state correctional facilities are 37 to $41 \%$ less likely to be 
tested at admission than prisoners in federal custody, after controlling for demographic and policy differences between inmates and institutions. Yet there are no significant differences in ever having been tested for HIV among prisoners who were tested before incarceration.

Institutional policies regarding HIV testing significantly structures and determines whether an inmate is tested for HIV at admission. The odds of inmates being tested at admission for the disease are 2.36 times greater for states with an entrance policy, relative to states without such a policy. Inmates in states with an entrance policy, but were tested on their own prior to incarceration, were $29 \%$ more likely to have ever been tested for HIV than inmates in other states without such a policy. Similarly, states with testing guidelines that mandate inmate testing while in custody or before release are $37 \%$ more likely to have been tested than states without such a policy. Inmates in states that designate testing high risk individuals are $23 \%$ more likely to be tested than inmates in states that lack this mandate. These results indicate that where an inmate serves time has significant implications for understanding potential health effects, with institutions and state policies determining whether an inmate is likely to learn about his health status in the absence of individual predispositions.

\section{HIV TEST RESULTS}

Table 3 presents our findings of the HIV status of inmates. Models 1-3 are for inmates who were tested at admission and had a positive result. The last three models include all inmates who are HIV+, regardless of whether they were tested before or during admission to prison. We pool these inmates to assess whether socio-economic and 
institutional correlates are attenuated when compared to inmates who were only tested at admission.

We find significant racial disparities in the likelihood of being HIV+. The odds of blacks testing positive for HIV are about 79\% greater than whites, even after accounting for where they serve time and observed testing policies. The odds of Latinos/Asians testing positive are even greater than blacks, with the likelihood of Latinos/Asians being HIV+ at admission being 94\% greater than whites of similar characteristics. Including blacks who were tested prior to incarceration lowers the odds of black inmates testing positive for HIV but the effects remain significant. However, the same is not true for Latinos/Asians. Including inmates who were tested prior to incarceration more than doubles the odds that Latinos/Asians are HIV+, indicating that testing at admission has significant import for inmate health assessments.

Educational disparities are also present in who is likely to have HIV. Although Table 2 showed that there were not testing disparities at admission for different educational groups, health disparities emerge quite strongly. Inmates with less than a high school diploma are more than twice as likely to be HIV+ than inmates with some college education. These effects are reduced slightly when inmates tested independent of the penal system are included, but the overall disparities remain.

Additionally, while there were significant differences in testing at admission for marital groups_-with the never married showing no differences in being tested-never married inmates are twice as likely to be HIV+ as married inmates. Including all prisoners tested before prison reduces the odds slightly; however the significant differences in HIV prevalence remain between the never married and married inmates. 
The odds of being HIV+ are about 30\% less among the release cohort of 20052009, but this finding disappears when we account for confinement type and institutional policies. The cohort admitted between 1990 and 1993 has significantly lower odds of being HIV+ by 57-61\%. All other release and admission cohorts show no signs of differences in HIV by cohort.

An inmate's confinement location is a significant predictor of HIV status. Inmates in local jails are more than twice as likely to be HIV+ than inmates in federal prison when tested at admission. However, this finding disappears when all inmates are included, regardless of whether they were tested at or before admission to prison. The odds that a state prisoner is HIV+ are about 67-72\% greater than inmates in federal prison, and significant differences remain after the inclusion of inmates who were tested prior to admission.

Institutional testing policies have a significant impact on determining whether an inmate is HIV+. States and institutions that have policies aimed at testing inmates upon entry in prison or jail have significantly lower odds being HIV+. Institutions that test inmates while they are in custody or upon release are more than twice as likely to be $\mathrm{HIV}+$ than inmates in prisons and jails without this policy. Restricted testing to high risk groups has no effect on whether an inmate tests positive for HIV.

\section{DISCUSSION}

Discussion about issues surrounding race and crime has long been mired in an unproductive mix of controversy and silence (Sampson and Wilson, 1995). This is an unfortunate happenstance since basic research on the relationship between race and crime and the system's responses have important bearing on theoretical and policy-relevant 
matters. One particular policy-relevant issue that has heretofore been neglected in social science research is the extent to which racialized patterns in crime and justice may be related to inmate release and community health outcomes generally, and to racial disparities in HIV testing before and during admission to prison in particular. An empirical investigation of this issue is a particularly important policy question from a community perspective because such basic knowledge can help forecast what sorts of health problems may be coming into communities upon inmate releases. Our investigation sought to examine how racial inequality in criminal justice may structure and recreate health inequities between inmates through a lack of systematic health testing and disease prevalence. Given that certain groups of respondents are significantly more likely to be tested than others, this is evidence that institutions play a role in structuring and discerning the health of particular socio-demographic groups due to variation in state and penal policies regarding testing. More importantly, health disparities are recreated when inmates exposed to institutional testing policies have similar outcomes as inmates who were tested independent of the criminal justice system.

Our findings indicate that institutional policies can recreate health outcomes for particular demographic groups (blacks) and even ameliorate testing disparities between groups (Latinos/Asians and inmates with less than a high school education). At the same time, we find evidence that institutionalization can structure health disparities (as in the case of marital groups) when none existed prior to incapacitation. Race effects in HIV testing and prevalence are robust to institution type and penal policies.

Although our effort was important and documented salient differences with respect to testing and identification of HIV, much more work remains to be done. For 
example, our effort did not examine the reasons why some but not all inmates are tested at admission nor are we able to assess racial differences in treatment. While health-care costs are likely to be a major component in decision-making regarding testing and treatment, it is important to attempt to screen and provide basic health care services to infected inmates. Additionally, our data did not allow us to examine how inmate sexual behavior serves as a potential transmittal for HIV. It is possible that individuals (from certain demographic groups) differentially engage in behavior that increases their probability of becoming infected. Documenting this process is integral to understanding transmission within and beyond the prison walls.

Our foray into this avenue of scholarship moves the field away from conventional discussions about race, crime and criminal justice. Much of this line of research has been long-concerned with understanding the roles of differential criminal participation and law enforcement, and much of the incarceration research tradition has tended to focus on the impact of incarceration on subsequent offending (Piquero and Blumstein, 2007). We join other researchers who have recently begun to focus their efforts on understanding the consequences of inmate re-entry into communities, and instead pay particular attention to the sorts of issues that inmates may bring back with them into their communities that could exert a negative toll. At the same time, we believe that the criminal justice system can have an indirect impact on the health and social well-being of communities by testing inmates for communicable diseases and getting inmates started upon a course of treatment. In this fashion, the system can at last be seen as doing some good, as opposed to always being viewed as doing much harm. 


\section{References}

Braithwaite, Ronald, and Kimberly Arriola. 2003. "Male Prisoners and HIV Prevention: A Call for Action Ignored.” American Journal of Public Health, 93:759-763.

Fiscella, Kevin, Peter Franks, Mark Doescher, and Barry Saver. 2002. “Disparities in Health Care by Race, Ethnicity, and Language Among the Insured.” Medical Care. 40:52-59

Hammett, T.M., P. Harmon, and W. Rhodes. 2002. “The burden of infectious disease among inmates of and releases from US correctional facilities, 1997.” American Journal of Public Health 92(11):1789-1794.

Horsburgh, Robert, Joseph Jarvis, Trudy McArther, Terri Ignacio, and Patricia Stock. 1990. “Seroconversions to HIV in Prison Inmates.” American Journal of Public Health, 80:209-210.

Johnson, Rucker and Steven Raphael. Forthcoming. “The Effects of Male Incarceration Dynamics on AIDS Infection Rates Among African-American Women and Men”. Journal of Law and Economics

Lynch, James P. and William J. Sabol. 2004. “Assessing the effects of mass incarceration on informal social control in communities.” Criminology \& Public Policy 3:267-294.

Maruschak, Laura. 2004. “HIV in Prisons” Washington, DC: Bureau of Justice Statistics.

----- 2006. “Medical Problems of Jail Inmates.” Washington, DC: Bureau of Justice Stats.

Nicholson-Crotty, Jill and Sean Nicholson-Crotty. 2004. "Social Construction and Policy Implementation: Inmate Health as a Public Health Issue.” Social Science Quarterly, 85:240-241. 
Pettit, Becky and Bruce Western. 2004. "Mass Imprisonment and the Life Course: Race and Class Inequality in U.S. Incarceration” American Sociological Review, 69: 151-169.

Piquero, Alex R. and Alfred Blumstein. 2007. “Does Incapacitation Reduce Crime?” Journal of Quantitative Criminology 23:267-286.

Piquero, Alex R., Valerie West, Jeffrey Fagan, and Jan Holland. 2006. "Neighborhood, Race, and the Economic Consequences of Incarceration in New York City, 1985-1996.” In Ruth D. Peterson and Lauren J. Krivo (Eds.), The Many Colors of Crime: Inequalities of Race, Ethnicity and Crime in America. New York, NY: New York University Press.

Rich, John. 2000. “The Health of African American Men.” Annals of the American Academy of Political and Social Science. 569: 149-59

Sabol, William and James P. Lynch. 2003. “Assessing the longer-run consequences of incarceration: Effects on families and employment.” In Darnell Hawkins, Samuel L. Myers, Jr., and Randolph Stone (Eds.), Crime Control and Social Justice: The Delicate Balance. Westport, CT: Greenwood Press.

Sampson, Robert J. and William Julius Wilson. 1995. "Toward a theory of race, crime, and urban inequality.” In John Hagan and Ruth D. Peterson (Eds.), Crime and Inequality. Stanford, CA: Stanford University Press.

Williams, David and Chiquita Collins. 1995. "US Socioeconomic and Racial Differences in Health: Patterns and Explanations.” Annual Review of Sociology 21:349-86

Williams, Robert, Susan Flocke, and Kurt Stange. 2001. "Race and Preventative Services Delivered Among Black Patients and White Patients Seen in Primary Care.” Medical Care. 11:1260-1267. 
Operationalization

Code

Dependent Variables

Tested at Admission

Ever tested

Test Result

Independent Variables

White

Black

Latino/Asian

LT High School

High School

Some College

Divorced/Widowed

Separated

Married

Age

Release 2003-2004

Release 2005-2009

Release 2010-2014

Release 2015-2019

Release After 2020

Admitted Before 1990

Admitted 1990-1993

Admitted 1994-1996

Admitted 1997-1999

Admitted 2000-2003

Federal Prison

Local Jail

State Prison

Entry

Custody or Release

High Risk
Was respondent tested for HIV at Admission?

Was the respondent ever tested for HIV?

Was the test result positive for HIV?

Respondent is a Non-Hispanic White

Respondent is a Non-Hispanic Black

Respondent is Latino or Asian

Respondent has less than a High School Diploma

Respondent has a High School Diploma

Respondent has Some College or More

Respondent is Divorced or Widowed

Respondent is Separated from Spouse

Respondent is Married

Age of Respondent

Respondent to be Released from Prison in 2003 or 2004

Respondent to be Released from Prison between 2005 and 2009

Respondent to be Released from Prison between 2010 and 2014

Respondent to be Released from Prison between 2015 and 2019

Respondent to be Released from Prison After 2020

Respondent Entered Prison before 1990

Respondent Entered Prison between 1990 and 1993

Respondent Entered Prison between 1994 and 1996

Respondent Entered Prison between 1997 and 1999

Respondent Entered Prison between 2000 and 2003

Respondent is in Federal Prison

Respondent is in Local Jail

Respondent is in State Prison

State Policy is to test all inmates upon entry?

State Policy is to test all inmates in custody or before release?

State or Federal Policy to test high risk populations?
Yes $=1$ and $\mathrm{No}=0$

Yes $=1$ and $\mathrm{No}=0$

Yes $=1$ and $\mathrm{No}=0$

Baseline Racial Comparison Group

Black $=1$

Latino $/$ Asian $=1$

$\mathrm{LT} \mathrm{HS}=1$

$\mathrm{HS}=1$

Baseline Education Group

Divorced/Widowed $=1$

Separated $=1$

Baseline Marital Group

Positive, Discrete Measure from 18-85

Baseline Reference Group

Released $=1$

Released $=1$

Released $=1$

Released $=1$

Baseline Reference Group

Admitted $=1$

Admitted $=1$

Admitted $=1$

Admitted $=1$

Baseline Reference Prison

Jail $=1$

State $=1$

Yes $=1$ and $\mathrm{No}=0$

Yes $=1$ and $\mathrm{No}=0$

Yes $=1$ and $\mathrm{No}=0$ 
Table 2: Odds Ratios Predicting the Likelihood of Having an HIV Test at Admission to Prison and Prior to Admission

\begin{tabular}{|c|c|c|c|c|c|c|}
\hline & \multicolumn{3}{|c|}{ Tested at Admission? } & \multicolumn{3}{|c|}{ Ever Tested? } \\
\hline & Model 1 & Model 2 & Model 3 & Model 4 & Model 5 & Model 6 \\
\hline Male & $\begin{array}{c}0.861^{*} \\
(0.06)\end{array}$ & $\begin{array}{c}0.886+ \\
(0.06)\end{array}$ & $\begin{array}{c}0.866^{*} \\
(0.06)\end{array}$ & $\begin{array}{c}0.587^{* * *} \\
(0.04)\end{array}$ & $\begin{array}{c}0.584^{* * *} \\
(0.04)\end{array}$ & $\begin{array}{c}0.585^{* * *} \\
(0.04)\end{array}$ \\
\hline Age & $\begin{array}{l}0.996 \\
(0.00)\end{array}$ & $\begin{array}{c}0.994+ \\
(0.00)\end{array}$ & $\begin{array}{l}0.995 \\
(0.00)\end{array}$ & $\begin{array}{c}0.994+ \\
(0.00)\end{array}$ & $\begin{array}{c}0.993^{*} \\
(0.00)\end{array}$ & $\begin{array}{l}0.993^{*} \\
(0.00)\end{array}$ \\
\hline Black & $\begin{array}{c}1.270^{* * *} \\
(0.08)\end{array}$ & $\begin{array}{c}1.287^{* * *} \\
(0.08)\end{array}$ & $\begin{array}{c}1.293^{* * *} \\
(0.08)\end{array}$ & $\begin{array}{c}1.336^{* * *} \\
(0.09)\end{array}$ & $\begin{array}{c}1.334^{* * *} \\
(0.09)\end{array}$ & $\begin{array}{c}1.332^{* * * *} \\
(0.09)\end{array}$ \\
\hline Latino/Asian & $\begin{array}{l}0.911 \\
(0.07)\end{array}$ & $\begin{array}{c}0.876+ \\
(0.07)\end{array}$ & $\begin{array}{l}0.991 \\
(0.07)\end{array}$ & $\begin{array}{c}0.672^{* * * *} \\
(0.05)\end{array}$ & $\begin{array}{c}0.659^{* * *} * \\
(0.05)\end{array}$ & $\begin{array}{c}0.671^{* * * *} \\
(0.05)\end{array}$ \\
\hline LT High School & $\begin{array}{l}1.013 \\
(0.08)\end{array}$ & $\begin{array}{l}1.068 \\
(0.09)\end{array}$ & $\begin{array}{l}1.035 \\
(0.08)\end{array}$ & $\begin{array}{c}0.743^{* * *} \\
(0.06)\end{array}$ & $\begin{array}{c}0.735^{* * *} \\
(0.06)\end{array}$ & $\begin{array}{c}0.733^{* * *} \\
(0.06)\end{array}$ \\
\hline High School & $\begin{array}{c}0.841^{*} \\
(0.07)\end{array}$ & $\begin{array}{l}0.943 \\
(0.08)\end{array}$ & $\begin{array}{l}0.927 \\
(0.08)\end{array}$ & $\begin{array}{c}0.855+ \\
(0.08)\end{array}$ & $\begin{array}{l}0.899 \\
(0.08)\end{array}$ & $\begin{array}{l}0.900 \\
(0.08)\end{array}$ \\
\hline Never Married & $\begin{array}{l}0.970 \\
(0.07)\end{array}$ & $\begin{array}{l}1.018 \\
(0.08)\end{array}$ & $\begin{array}{l}1.030 \\
(0.08)\end{array}$ & $\begin{array}{l}0.952 \\
(0.08)\end{array}$ & $\begin{array}{l}0.957 \\
(0.08)\end{array}$ & $\begin{array}{l}0.957 \\
(0.08)\end{array}$ \\
\hline Divorced/Widowed & $\begin{array}{l}1.213^{*} \\
(0.11)\end{array}$ & $\begin{array}{c}1.260^{* *} \\
(0.11)\end{array}$ & $\begin{array}{l}1.226^{*} \\
(0.11)\end{array}$ & $\begin{array}{l}1.038 \\
(0.10)\end{array}$ & $\begin{array}{l}1.063 \\
(0.10)\end{array}$ & $\begin{array}{l}1.061 \\
(0.10)\end{array}$ \\
\hline Separated & $\begin{array}{c}1.243+ \\
(0.16)\end{array}$ & $\begin{array}{l}1.335^{*} \\
(0.18)\end{array}$ & $\begin{array}{l}1.348^{*} \\
(0.18)\end{array}$ & $\begin{array}{l}0.994 \\
(0.13)\end{array}$ & $\begin{array}{l}1.032 \\
(0.14)\end{array}$ & $\begin{array}{l}1.031 \\
(0.14)\end{array}$ \\
\hline Release 2005-2009 & $\begin{array}{l}1.154^{*} \\
(0.07)\end{array}$ & $\begin{array}{l}0.959 \\
(0.06)\end{array}$ & $\begin{array}{l}0.978 \\
(0.06)\end{array}$ & $\begin{array}{l}0.991 \\
(0.07)\end{array}$ & $\begin{array}{c}0.817^{* *} \\
(0.06)\end{array}$ & $\begin{array}{c}0.817^{* *} \\
(0.06)\end{array}$ \\
\hline Release 2010-2014 & $\begin{array}{l}0.982 \\
(0.11)\end{array}$ & $\begin{array}{c}0.803^{*} \\
(0.09)\end{array}$ & $\begin{array}{c}0.811+ \\
(0.09)\end{array}$ & $\begin{array}{c}0.726^{*} \\
(0.09)\end{array}$ & $\begin{array}{c}0.607^{* * *} * \\
(0.08)\end{array}$ & $\begin{array}{c}0.610^{* * * *} \\
(0.08)\end{array}$ \\
\hline Release 2015-2019 & $\begin{array}{l}0.901 \\
(0.14)\end{array}$ & $\begin{array}{c}0.751+ \\
(0.12)\end{array}$ & $\begin{array}{l}0.782 \\
(0.12)\end{array}$ & $\begin{array}{l}0.984 \\
(0.20)\end{array}$ & $\begin{array}{l}0.849 \\
(0.17)\end{array}$ & $\begin{array}{l}0.865 \\
(0.18)\end{array}$ \\
\hline Release After 2020 & $\begin{array}{l}1.033 \\
(0.16)\end{array}$ & $\begin{array}{l}0.890 \\
(0.14)\end{array}$ & $\begin{array}{l}0.937 \\
(0.14)\end{array}$ & $\begin{array}{l}0.798 \\
(0.14)\end{array}$ & $\begin{array}{c}0.686^{*} \\
(0.12)\end{array}$ & $\begin{array}{c}0.688^{*} \\
(0.13)\end{array}$ \\
\hline Admitted 1990-1993 & $\begin{array}{l}1.187 \\
(0.20)\end{array}$ & $\begin{array}{l}1.290 \\
(0.22)\end{array}$ & $\begin{array}{l}1.309 \\
(0.22)\end{array}$ & $\begin{array}{l}1.000 \\
(0.23)\end{array}$ & $\begin{array}{l}1.016 \\
(0.23)\end{array}$ & $\begin{array}{l}1.009 \\
(0.23)\end{array}$ \\
\hline Admitted 1994-1996 & $\begin{array}{l}1.055 \\
(0.16)\end{array}$ & $\begin{array}{l}1.142 \\
(0.18)\end{array}$ & $\begin{array}{l}1.133 \\
(0.18)\end{array}$ & $\begin{array}{l}1.261 \\
(0.25)\end{array}$ & $\begin{array}{l}1.293 \\
(0.26)\end{array}$ & $\begin{array}{l}1.299 \\
(0.26)\end{array}$ \\
\hline Admitted 1997-1999 & $\begin{array}{l}0.867 \\
(0.11)\end{array}$ & $\begin{array}{l}0.940 \\
(0.12)\end{array}$ & $\begin{array}{l}0.965 \\
(0.13)\end{array}$ & $\begin{array}{l}1.229 \\
(0.21)\end{array}$ & $\begin{array}{l}1.243 \\
(0.21)\end{array}$ & $\begin{array}{l}1.254 \\
(0.21)\end{array}$ \\
\hline Admitted 2000-2003 & $\begin{array}{c}0.620^{* * *} \\
(0.07)\end{array}$ & $\begin{array}{l}0.741^{*} \\
(0.09)\end{array}$ & $\begin{array}{l}0.749^{*} \\
(0.09)\end{array}$ & $\begin{array}{l}1.235 \\
(0.19)\end{array}$ & $\begin{array}{l}1.411^{*} \\
(0.22)\end{array}$ & $\begin{array}{l}1.418^{*} \\
(0.22)\end{array}$ \\
\hline Local Jail & & $\begin{array}{c}0.278^{* * *} \\
(0.03)\end{array}$ & $\begin{array}{c}0.350^{* * *} * \\
(0.05)\end{array}$ & & $\begin{array}{c}0.610^{* * * *} \\
(0.07)\end{array}$ & $\begin{array}{c}0.647^{* *} \\
(0.09)\end{array}$ \\
\hline State Prison & & $\begin{array}{c}0.625^{* * *} \\
(0.05)\end{array}$ & $\begin{array}{c}0.587^{* * *} * \\
(0.05)\end{array}$ & & $\begin{array}{l}0.905 \\
(0.09)\end{array}$ & $\begin{array}{l}0.896 \\
(0.10)\end{array}$ \\
\hline Entry & & & $\begin{array}{c}2.357^{* * * *} \\
(0.23)\end{array}$ & & & $\begin{array}{l}1.287^{*} \\
(0.14)\end{array}$ \\
\hline Custody or Release & & & $\begin{array}{c}1.367^{* *} \\
(0.15)\end{array}$ & & & $\begin{array}{l}1.055 \\
(0.15)\end{array}$ \\
\hline High Risk & & & $\begin{array}{c}1.228^{* *} \\
(0.09)\end{array}$ & & & $\begin{array}{l}1.057 \\
(0.09)\end{array}$ \\
\hline $\mathrm{N}$ & 10640 & 10640 & 10640 & 5603 & 5603 & 5603 \\
\hline
\end{tabular}

Data source: Survey of Inmates in State \& Federal Prisons, 2004 and Survey of Inmates in Local Jails, 2002. White, college/some college, married, Entrying prison before 1990, and having a release date of 2003-2004 are the reference categories. All models are clustered by state to account for different variance patterns, and we report robust standard errors. 
Table 3: Odds Ratios Predicting the Likelihood of Testing HIV+ at Admission and Prior to Admission

\begin{tabular}{|c|c|c|c|c|c|c|}
\hline & \multicolumn{3}{|c|}{ HIV+ at Admission } & \multicolumn{3}{|c|}{ All HIV+ } \\
\hline & Model 1 & Model 2 & Model 3 & Model 4 & Model 5 & Model 6 \\
\hline Male & $\begin{array}{l}0.748 \\
(0.14)\end{array}$ & $\begin{array}{c}0.716+ \\
(0.13)\end{array}$ & $\begin{array}{l}0.739 \\
(0.14)\end{array}$ & $\begin{array}{l}0.774 \\
(0.13)\end{array}$ & $\begin{array}{c}0.749+ \\
(0.13)\end{array}$ & $\begin{array}{l}0.766 \\
(0.13)\end{array}$ \\
\hline Age & $\begin{array}{c}1.057^{* * *} \\
(0.01)\end{array}$ & $\begin{array}{c}1.058^{* * *} \\
(0.01)\end{array}$ & $\begin{array}{c}1.056^{* * *} \\
(0.01)\end{array}$ & $\begin{array}{c}1.057^{* * *} \\
(0.01)\end{array}$ & $\begin{array}{c}1.058^{* * *} \\
(0.01)\end{array}$ & $\begin{array}{c}1.056^{* * *} \\
(0.01)\end{array}$ \\
\hline Black & $\begin{array}{c}1.782^{* *} \\
(0.36)\end{array}$ & $\begin{array}{c}1.799 * * \\
(0.36)\end{array}$ & $\begin{array}{c}1.786^{* *} \\
(0.36)\end{array}$ & $\begin{array}{c}1.729^{* *} \\
(0.32)\end{array}$ & $\begin{array}{c}1.750^{* *} \\
(0.33)\end{array}$ & $\begin{array}{c}1.743^{* *} \\
(0.33)\end{array}$ \\
\hline Latino/Asian & $\begin{array}{c}1.894^{* *} \\
(0.45)\end{array}$ & $\begin{array}{c}1.994^{* *} \\
(0.48)\end{array}$ & $\begin{array}{c}1.935^{* *} \\
(0.47)\end{array}$ & $\begin{array}{c}1.950^{* *} \\
(0.43)\end{array}$ & $\begin{array}{c}2.024^{* *} \\
(0.45)\end{array}$ & $\begin{array}{c}2.007^{* *} \\
(0.45)\end{array}$ \\
\hline LT High School & $\begin{array}{c}2.245^{* *} \\
(0.64)\end{array}$ & $\begin{array}{c}2.040^{*} \\
(0.58)\end{array}$ & $\begin{array}{c}2.025^{*} \\
(0.58)\end{array}$ & $\begin{array}{c}2.028^{* *} \\
(0.52)\end{array}$ & $\begin{array}{l}1.889^{*} \\
(0.48)\end{array}$ & $\begin{array}{l}1.868^{*} \\
(0.48)\end{array}$ \\
\hline High School & $\begin{array}{l}1.670 \\
(0.53)\end{array}$ & $\begin{array}{l}1.530 \\
(0.49)\end{array}$ & $\begin{array}{l}1.527 \\
(0.49)\end{array}$ & $\begin{array}{l}1.439 \\
(0.41)\end{array}$ & $\begin{array}{l}1.383 \\
(0.40)\end{array}$ & $\begin{array}{l}1.379 \\
(0.40)\end{array}$ \\
\hline Never Married & $\begin{array}{c}2.129^{* *} \\
(0.54)\end{array}$ & $\begin{array}{c}2.033^{* *} \\
(0.52)\end{array}$ & $\begin{array}{c}1.979^{* *} \\
(0.50)\end{array}$ & $\begin{array}{c}1.995^{* *} \\
(0.47)\end{array}$ & $\begin{array}{c}1.937^{* *} \\
(0.46)\end{array}$ & $\begin{array}{c}1.907^{* *} \\
(0.45)\end{array}$ \\
\hline Divorced/Widowed & $\begin{array}{l}0.999 \\
(0.29)\end{array}$ & $\begin{array}{l}0.955 \\
(0.28)\end{array}$ & $\begin{array}{l}0.962 \\
(0.28)\end{array}$ & $\begin{array}{l}1.030 \\
(0.28)\end{array}$ & $\begin{array}{l}1.006 \\
(0.27)\end{array}$ & $\begin{array}{l}1.006 \\
(0.28)\end{array}$ \\
\hline Separated & $\begin{array}{l}1.697 \\
(0.61)\end{array}$ & $\begin{array}{l}1.601 \\
(0.57)\end{array}$ & $\begin{array}{l}1.594 \\
(0.57)\end{array}$ & $\begin{array}{l}1.536 \\
(0.52)\end{array}$ & $\begin{array}{l}1.486 \\
(0.51)\end{array}$ & $\begin{array}{l}1.492 \\
(0.51)\end{array}$ \\
\hline Released 2005-2009 & $\begin{array}{c}0.700+ \\
(0.13)\end{array}$ & $\begin{array}{l}0.756 \\
(0.15)\end{array}$ & $\begin{array}{l}0.737 \\
(0.14)\end{array}$ & $\begin{array}{l}0.759 \\
(0.14)\end{array}$ & $\begin{array}{l}0.778 \\
(0.15)\end{array}$ & $\begin{array}{l}0.761 \\
(0.14)\end{array}$ \\
\hline Released 2010-2014 & $\begin{array}{l}1.181 \\
(0.35)\end{array}$ & $\begin{array}{l}1.347 \\
(0.41)\end{array}$ & $\begin{array}{l}1.296 \\
(0.40)\end{array}$ & $\begin{array}{l}1.264 \\
(0.36)\end{array}$ & $\begin{array}{l}1.348 \\
(0.39)\end{array}$ & $\begin{array}{l}1.297 \\
(0.38)\end{array}$ \\
\hline Release 2015-2019 & $\begin{array}{l}1.067 \\
(0.47)\end{array}$ & $\begin{array}{l}1.176 \\
(0.52)\end{array}$ & $\begin{array}{l}1.085 \\
(0.48)\end{array}$ & $\begin{array}{l}1.061 \\
(0.46)\end{array}$ & $\begin{array}{l}1.105 \\
(0.48)\end{array}$ & $\begin{array}{l}1.005 \\
(0.44)\end{array}$ \\
\hline Release After 2020 & $\begin{array}{l}1.353 \\
(0.52)\end{array}$ & $\begin{array}{l}1.468 \\
(0.57)\end{array}$ & $\begin{array}{l}1.379 \\
(0.53)\end{array}$ & $\begin{array}{l}1.361 \\
(0.52)\end{array}$ & $\begin{array}{l}1.399 \\
(0.54)\end{array}$ & $\begin{array}{l}1.310 \\
(0.50)\end{array}$ \\
\hline Admitted 1990-1993 & $\begin{array}{c}0.423+ \\
(0.20)\end{array}$ & $\begin{array}{c}0.395+ \\
(0.19)\end{array}$ & $\begin{array}{c}0.407+ \\
(0.20)\end{array}$ & $\begin{array}{c}0.410+ \\
(0.20)\end{array}$ & $\begin{array}{c}0.387^{*} \\
(0.18)\end{array}$ & $\begin{array}{c}0.397+ \\
(0.19)\end{array}$ \\
\hline Admitted 1994-1996 & $\begin{array}{l}0.693 \\
(0.27)\end{array}$ & $\begin{array}{l}0.655 \\
(0.25)\end{array}$ & $\begin{array}{l}0.673 \\
(0.26)\end{array}$ & $\begin{array}{l}0.641 \\
(0.24)\end{array}$ & $\begin{array}{l}0.607 \\
(0.23)\end{array}$ & $\begin{array}{l}0.630 \\
(0.24)\end{array}$ \\
\hline Admitted 1997-1999 & $\begin{array}{l}0.724 \\
(0.23)\end{array}$ & $\begin{array}{l}0.686 \\
(0.22)\end{array}$ & $\begin{array}{l}0.710 \\
(0.23)\end{array}$ & $\begin{array}{l}0.766 \\
(0.23)\end{array}$ & $\begin{array}{l}0.730 \\
(0.22)\end{array}$ & $\begin{array}{l}0.764 \\
(0.24)\end{array}$ \\
\hline Admitted 2000-2003 & $\begin{array}{l}1.066 \\
(0.30)\end{array}$ & $\begin{array}{l}0.980 \\
(0.28)\end{array}$ & $\begin{array}{l}1.015 \\
(0.29)\end{array}$ & $\begin{array}{l}0.913 \\
(0.25)\end{array}$ & $\begin{array}{l}0.876 \\
(0.24)\end{array}$ & $\begin{array}{l}0.916 \\
(0.25)\end{array}$ \\
\hline Local Jail & & $\begin{array}{l}2.121^{*} \\
(0.78)\end{array}$ & $\begin{array}{c}2.019+ \\
(0.85)\end{array}$ & & $\begin{array}{l}1.309 \\
(0.41)\end{array}$ & $\begin{array}{l}1.353 \\
(0.49)\end{array}$ \\
\hline State Prison & & $\begin{array}{l}1.722^{*} \\
(0.39)\end{array}$ & $\begin{array}{l}1.660^{*} \\
(0.42)\end{array}$ & & $\begin{array}{l}1.533^{*} \\
(0.33)\end{array}$ & $\begin{array}{c}1.503+ \\
(0.37)\end{array}$ \\
\hline Entry & & & $\begin{array}{c}0.564^{*} \\
(0.14)\end{array}$ & & & $\begin{array}{c}0.625+ \\
(0.15)\end{array}$ \\
\hline Custody or Release & & & $\begin{array}{c}1.957^{* *} \\
(0.45)\end{array}$ & & & $\begin{array}{c}2.152^{* * *} \\
(0.49)\end{array}$ \\
\hline High Risk & & & $\begin{array}{l}0.985 \\
(0.20)\end{array}$ & & & $\begin{array}{l}1.072 \\
(0.21)\end{array}$ \\
\hline $\mathrm{N}$ & 8453 & 8453 & 8453 & 11756 & 11756 & 11756 \\
\hline
\end{tabular}

Data source: Survey of Inmates in State \& Federal Prisons, 2004 and Survey of Inmates in Local Jails, 2002. White, college/some college, married, Entrying prison before 1990, and having a release date of 2003-2004 are the reference categories. All models are clustered by state to account for different variance patterns, and we report robust standard errors. 